(c) 2018 - ISSN 1807-2577

\title{
Evaluation of flow and filling of root canal sealers using different methodologies
}

\author{
Avaliação do escoamento e preenchimento de cimentos obturadores \\ utilizando diferentes metodologias
}

\author{
Fernanda Ferrari Esteves TORRES ${ }^{a}$ (D), Juliane Maria GUERREIRO-TANOMARUa (D), \\ Jader Camilo PINTOa (D), Idomeo BONETTI-FILHOa (D), Mário TANOMARU-FILHO ${ }^{a *}$ (D) \\ aUNESP - Universidade Estadual Paulista, Faculdade de Odontologia de Araraquara, Departamento de Odontologia \\ Restauradora, Araraquara, SP, Brasil
}

\begin{abstract}
How to cite: Torres FFE, Guerreiro-Tanomaru JM, Pinto JC, Bonetti-Filho I, Tanomaru-Filho M. Evaluation of flow and filling of root canal sealers using different methodologies. Rev Odontol UNESP. 2019;48:e20190112.

https://doi.org/10.1590/1807-2577.11219
\end{abstract}

\begin{abstract}
Resumo
Introdução: Escoamento e capacidade de preenchimento de cimentos obturadores são indispensáveis para um selamento hermético do canal radicular. Microtomografia computadorizada (micro-CT) pode ser utilizada como uma metodologia complementar para avaliação de tais propriedades. Objetivo: Avaliar escoamento e capacidade de preenchimento de AH Plus, Endofill e Sealapex, por meio de metodologia convencional e micro-CT. Material e método: 0 escoamento dos cimentos foi analisado de acordo com as normas ISO 6876/2012 e complementado pela avaliação em área. Placas de vidro foram confeccionadas nos diâmetros de $1 \times 1 \times 2 \mathrm{~mm}$ e $1 \times 1 \times 1 \mathrm{~mm}$ (comprimento, largura e altura), com uma cavidade central e quatro canaletas nas direções horizontal e vertical. Cada material foi colocado na cavidade central. Outra placa de vidro e um peso de metal foram colocados sobre o cimento e mantidos por 10 minutos. 0 conjunto placa de vidro/cimento foi escaneado usando micro-CT. 0 escoamento foi calculado por medição linear do material nas canaletas. 0 preenchimento $\left(\mathrm{mm}^{3}\right)$ central foi calculado na cavidade central e o preenchimento lateral foi medido até $2 \mathrm{~mm}$ a partir da cavidade central. Os dados foram submetidos aos testes ANOVA/Tukey $(\alpha=0.05)$. Resultado: Todos os cimentos avaliados apresentaram escoamento de acordo com as normas ISO 6876. Os materiais mostraram capacidade de preenchimento da cavidade central superior a $80 \%$ e preenchimento lateral superior a $75 \%$.

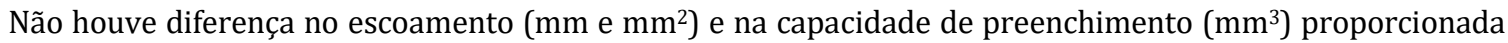
pelos materiais $(\mathrm{p}>0.05)$. Conclusão: Todos os cimentos obturadores avaliados mostraram adequado escoamento e capacidade de preenchimento, sugerindo a aplicação clínica dos mesmos.
\end{abstract}

Descritores: Endodontia; materiais dentários; microtomografia por raio-X.

\begin{abstract}
Introduction: Flow and filling ability of root canal sealers are indispensable for hermetic sealing of the root canal. Micro-computed tomography (micro-CT) can be used as a complementary methodology to evaluate such properties. Objective: To evaluate the flow and filling ability of AH Plus, Endofill and Sealapex by conventional methodology and micro-CT. Material and method: The flow of the sealers was analyzed according to ISO 6876/2012 and complemented by the area evaluation. Glass plates were manufactured with diameters of $1 \times 1 \times 2 \mathrm{~mm}$ and $1 \times 1 \times 1 \mathrm{~mm}$ (length, width and height), with a central cavity and four grooves in the horizontal and vertical directions. Each material was placed in the central cavity. Another glass plate and a metal weight were placed on the cement and kept for 10 minutes. The glass plate/sealer set was scanned using micro-CT. The flow was calculated by linear measurement of the material in the grooves. The central filling $\left(\mathrm{mm}^{3}\right)$ was calculated in the central cavity and the lateral filling was measured up to $2 \mathrm{~mm}$ from the central cavity. Data were submitted to ANOVA/Tukey tests $(\alpha=0.05)$. Result: All evaluated sealers presented flow according to ISO 6876 standards. The materials showed central cavity filling capacity higher than $80 \%$ and lateral filling greater than $75 \%$. There was no difference in flow ( $\mathrm{mm}$ and $\mathrm{mm}^{2}$ ) and in the filling ability $\left(\mathrm{mm}^{3}\right)$ provided by the materials $(\mathrm{p}>0.05)$. Conclusion: All evaluated root canal sealers showed adequate flow and filling capacity, suggesting their clinical application.
\end{abstract}

Descriptors: Endodontics; dental materials; X-ray microtomography.

This is an Open Access article distributed under the terms of the Creative Commons Attribution License, which permits unrestricted use, distribution, and reproduction in any medium, provided the original work is properly cited. 


\section{INTRODUCTION}

A complete root canal filling is substantial for long-term success of endodontic treatment ${ }^{1}$. The obturation is classically performed using gutta-percha and different types of root canal sealers ${ }^{2}$. The root canal sealers fill the gaps between gutta-percha cones and the dentine walls ${ }^{3}$. Therefore, these materials should present adequate physical properties ${ }^{4}$.

Among the important physical properties to a proper obturation, the flow of endodontic sealers allows their deeper penetrability into the irregularities of the root canal system, which contribute to own interlocking between sealer and dentine ${ }^{5}$. Therefore, the flow of endodontic sealers may be evaluated by the ISO $6876 / 2012^{6}$ standard, which recommend that the materials have a minimum of $17 \mathrm{~mm}$ of flow. However, the main limitation of this conventional test is its incapability to evaluate also the filling ability of the materials ${ }^{7}$.

A previous study ${ }^{7}$ proposed the micro-computed tomography (micro-CT) as a reliable method to assess the flow and filling of root-end filling materials using a single test, in a 3D way. The authors used glass plates in a similar manner to the conventional ISO test, and observed an absence of correlation between the flow and filling properties. Up to now, there is no study applying this method to evaluate root canal sealers.

Endodontic sealers are divided according to their main components ${ }^{8}$, and their properties are directly related to their composition ${ }^{9}$. AH Plus (Dentsply DeTrey, Konstanz, Germany) is an epoxy resin-based root canal sealer that is considered the gold standard for physical properties ${ }^{10}$. Fill Canal (Technew Com. e Ind. Ltda., Rio de Janeiro, RJ, Brazil) is a zinc oxide and eugenol-based sealer that is routinely used in the Brazilian dental practice ${ }^{11}$. Sealapex (SybronEndo, Glendona, CA, USA) is a root canal sealer based on calcium hydroxide ${ }^{12}$. Previous studies showed flow in accordance with the ISO 6876 for sealers based on calcium hydroxide, epoxy resin and zinc oxide and eugenol ${ }^{12,13}$. However, the comparison between flow and filling of these sealers was not assessed yet.

Based on this gap in the literature, the aim of this study was to evaluate the flow and filling ability of root canal sealers based on different components by using conventional tests and micro-CT. The null hypotheses were that there is no difference between the sealers, and the properties of flow and filling ability are associated.

\section{MATERIAL AND METHOD}

The endodontic sealers used in this study, their respective manufacturers, and compositions are described in Table 1.

Table 1. Endodontic materials, their manufacturers, and composition

\begin{tabular}{|c|c|c|}
\hline Material & Manufacturer & Composition \\
\hline AH Plus & $\begin{array}{l}\text { DentsplyDeTrey, Konstanz, } \\
\text { Germany }\end{array}$ & $\begin{array}{l}\text { Paste A: bisphenol epoxy resin-A, bisphenol epoxy resin-F, } \\
\text { calcium tungstate, zirconium oxide, silica, iron oxide pigments. } \\
\text { Paste B: dibenzyldiamine, aminodiamantana, } \\
\text { tricyclodecane-diamine, calcium tungstate, zirconium oxide, } \\
\text { silica, silicone oil. }\end{array}$ \\
\hline Fill Canal & $\begin{array}{l}\text { Technew Com. Ind. Ltda. Rio de } \\
\text { Janeiro, RJ, Brazil }\end{array}$ & $\begin{array}{l}\text { Powder: hydrogen resin, bismuth subcarbonate, barium } \\
\text { sulfate and sodium borate }\end{array}$ \\
\hline Sealapex & $\begin{array}{l}\text { SybronEndo - Sybron Dental } \\
\text { Specialties, Glendona, CA, USA }\end{array}$ & $\begin{array}{l}\text { Liquid: eugenol and sweet almond oil. } \\
\text { Base paste: sulphonamide resin, } \mathrm{N} \text {-ethyl toluene, silicon } \\
\text { dioxide, zinc oxide, calcium oxide; }\end{array}$ \\
\hline & & $\begin{array}{l}\text { Catalyst paste: isobutyl salicylate resin, silicon dioxide, } \\
\text { bismuth trioxide, titanium dioxide, pigments }\end{array}$ \\
\hline
\end{tabular}




\section{Flow ( $\mathrm{mm}$ and $\left.\mathrm{mm}^{2}\right)$}

The flow test was performed based on ISO 6876:2012 standard 6 (Figure 1). After mixing of the sealers, $0.05 \mathrm{~mL}$ of the material was placed in the center of a glass plate using a graduated disposable syringe $(n=10)$. Then, another glass plate $(20 \mathrm{~g})$ and a metal weight $(100 \mathrm{~g})$ were placed over the sealer, and kept for 10 minutes. So, the diameters of the sealer disks were measured using a digital caliper. The materials were photographed on the plate with a millimeter ruler for evaluation of the flow in area $\left(\mathrm{mm}^{2}\right)$, according to Tanomaru-Filho et al. ${ }^{14}$ The flow area of the sealers was obtained using Image Tool 3.0 software (UTHSCSA, San Antonio, TX, USA).
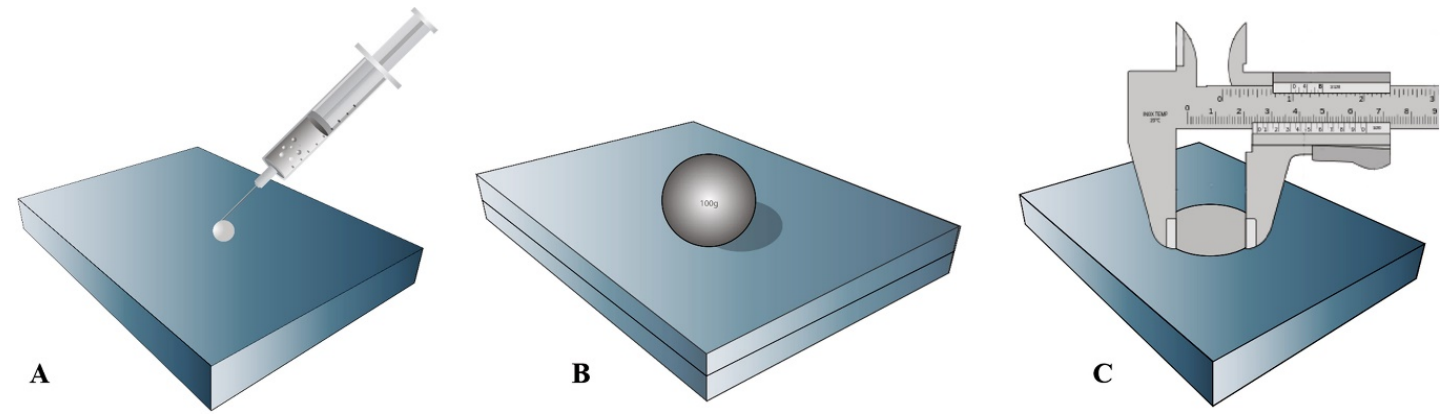

Figure 1. Schematic figure representing the flow assessment according to ISO 6876/2012. (A) $0.05 \mathrm{~mL}$ of the material was placed in the center of the glass plate by a graduated syringe; (B) Another glass plate and a metal load were placed over the sealer; $(C)$ The diameters of the sealer disks were measured using a digital caliper.

\section{Flow and Filling Ability Evaluated by Micro-CT}

A glass plate was manufactured with a central cavity $(1 \times 1 \times 2 \mathrm{~mm})$ (length, width, and height) and grooves extending out horizontally and vertically to the $4 \operatorname{sides}^{7}$ (Figure 2A). Another dimension $(1 \times 1 \times 1 \mathrm{~mm}$ - length, width, and height) was proposed for comparison. In a similar manner to the ISO $6876^{6}$ test, an amount of $0.05 \mathrm{~mL}$ of each sealer was placed in the central cavity of the bottom glass plate, and another glass plate (20 g) and metal weight (100 g) were placed on the sealers and kept for 10 minutes (Figure 2B). The glass plates/sealer set was scanned with the SkyScan 1176 micro-CT system (SkyScan, Bruker, Kontich, Belgium) (Figure 2C). The micro-CT parameters were $9 \mu \mathrm{m}$ voxel size, $90 \mathrm{kVp}, 278 \mathrm{~mA}, 0.1 \mathrm{~mm}$ copper filter, and $360^{\circ}$ scanning. The linear flow $(\mathrm{mm})$ on each side of the grooves (horizontal and vertical) was analyzed. The filling in volume $\left(\mathrm{mm}^{3}\right)$ of the sealers in the central area was determined as the central cavity filling. The filling in volume $\left(\mathrm{mm}^{3}\right)$ of the materials in the lateral areas was determined up to $2 \mathrm{~mm}$ for each side of the central cavity. The images were reconstructed using NRecon software (V1.6.10.4; Bruker). The flow into the grooves besides the central and lateral fillings were calculated using the CTAn software (V1.15.4.0; Bruker).

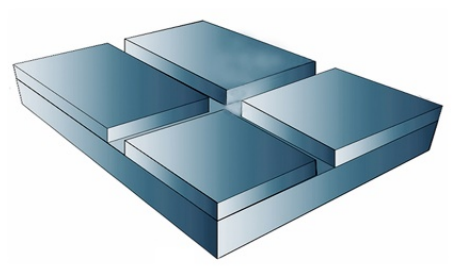

$\mathbf{A}$

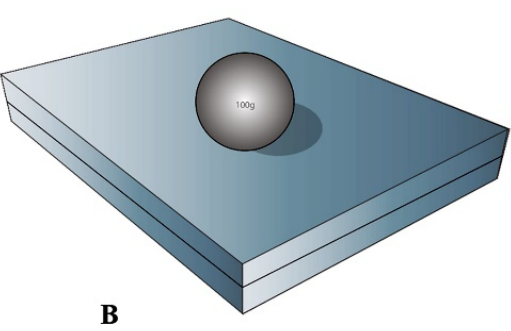

B

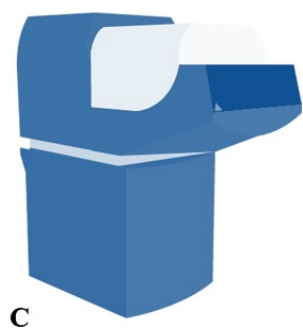

C

Figure 2. Schematic figure representing the flow and filling assessments by using micro-CT. (A) Glass plates were manufactured with a central cavity and grooves extending out horizontally and vertically; (B) Another glass plate and a metal load were placed after delivery $0.05 \mathrm{~mL}$ of the sealer in the central cavity of the bottom glass plate;

(C) The glass plates/sealer set was scanned by micro-CT. 


\section{Statistical Analysis}

The normality of the data was tested using the Kolmogorov-Smirnov test. Statistical analysis was performed with ANOVA and Tukey parametric tests. The level of significance was set at $\mathrm{p}<0.05$.

\section{RESULT}

\section{Flow ( $\mathrm{mm}$ and $\mathrm{mm}^{2}$ )}

All the sealers evaluated had a flow above the minimum $(17 \mathrm{~mm})$ recommended by the ISO 6876/2012. Although AH Plus had the highest flow value, there was no statistically significant difference among the materials ( $p>0.05$ ). The assessment in area also showed similarities between the sealers ( $p>0.05)$. The results are represented in Table 2 .

Table 2. Mean and standard deviation of the results of flow $\left(\mathrm{mm}\right.$ and $\left.\mathrm{mm}^{2}\right)$ of root canal sealers

\begin{tabular}{cccc}
\hline & AH Plus & Fill Canal & Sealapex \\
\hline Flow ISO 6876 $(\mathrm{mm})$ & $21.39(0.76)$ & $20.50(1.64)$ & $20.15(0.76)$ \\
Flow area $\left(\mathrm{mm}^{2}\right)$ & $546.1(49.15)$ & $536.7(87.33)$ & $527.6(69.53)$ \\
\hline
\end{tabular}

There was no statistically significant difference between the sealers ( $p>0.05)$.

\section{Flow and Filling Ability Evaluated by Micro-CT}

The results are showed in Table 3. Independently of the test model used, there was no statistically significant difference between the linear flow $(\mathrm{mm})$, central and lateral fillings $\left(\mathrm{mm}^{3}\right)$ observed for AH Plus, Sealapex and Fill Canal ( $p>0.05$ ). All the sealers had a central filling above $80 \%$ and a lateral filling above $75 \%$, in both diameters of test models.

Table 3. Mean and standard deviation of the results of flow $(\mathrm{mm})$ and filling $(\%)$ of endodontic materials evaluated in micro-CT using test models with different sizes (length, width, and height)

\begin{tabular}{cccc}
\hline & AH Plus & Fill Canal & Sealapex \\
\hline Linear Flow (mm) & & & \\
$1 \times 1 \times 1 \mathrm{~mm}$ & $13.46(1.49)$ & $11.49(1.28)$ & $11.65(1.24)$ \\
$1 \times 1 \times 2 \mathrm{~mm}$ & $8.32(0.97)$ & $9.25(0.48)$ & $8.99(0.37)$ \\
Central Filling (\%) & & & \\
$1 \times 1 \times 1 \mathrm{~mm}$ & $84.67(3.20)$ & $82.50(4.18)$ & $82.33(10.09)$ \\
$1 \times 1 \times 2 \mathrm{~mm}$ & $89.50(9.61)$ & $80.75(4.68)$ & $89.42(6.44)$ \\
Lateral Filling (\%) & & & $77.63(12.72)$ \\
$1 \times 1 \times 1 \mathrm{~mm}$ & $84.25(5.65)$ & $76.17(6.55)$ & $85.46(1.046)$ \\
$1 \times 1 \times 2 \mathrm{~mm}$ & $86.68(11.38)$ & $76.11(7.17)$ & \\
\hline
\end{tabular}

There was no statistically significant difference between the sealers and between the different test models ( $p>0.05$ ).

\section{DISCUSSION}

This study evaluated the flow and filling properties of endodontics sealers based on different components to compare the difference between the materials, besides differences between the properties evaluated. Our null hypothesis was accepted since there was no difference between the sealers and the flow and filling properties were also similar. 
An appropriate flow ability of the root canal sealers is a desired property in order to fill irregularities ${ }^{15}$. Moreover, for the endodontic sealers to exert their antimicrobial properties, a proper flow able their diffusion into the complex anatomy of the root canal, which is difficult to access and disinfect ${ }^{16}$. Therefore, the root canal sealers could aid in the elimination of the remaining microorganisms, increasing the success rates of the endodontic treatment ${ }^{17}$. In this study, as previously performed, two methods of analysis were used to conventional evaluation of the sealers flow ${ }^{12}$. We used the method preconized by the ISO 6876/2012, which record the diameter of the sealers after to put a glass plate and a metal weight on the material. After that, we evaluated all the area occupied by the sealers, as an additional analysis ${ }^{14}$.

All the sealers evaluated in the current study showed flow in accordance with the ISO ${ }^{6}$ standard, which recommends a minimum value of $17 \mathrm{~mm}$. Zinc oxide and eugenol-based materials are widely used in Endodontics ${ }^{11}$. However, in the best of our knowledge, there is no study evaluating the flow property for Fill Canal. Nevertheless, many studies evaluated other sealers based on zinc oxide and eugenol, such as Endofill (Dentsply-Maillefer, Dentsply Indústria e Comércio Ltda., Petrópolis, RJ, Brazil). Marin-Bauza et al. ${ }^{13}$ attributed the high flow of Endofill to the presence of hydrogenated resin on its formula. This component is also present in Fill Canal. Although the flow value of AH Plus was numerically higher than Sealapex and Fill Canal, the sealers had a statistically similar flow. The high flow of AH Plus was described in previous studies $12,13,15-18$. The greater concentration of epoxy resin in AH Plus is considered the reason for its high flow rate ${ }^{18}$. The flow of the materials is also affected by the size of their particles, whereas small particles allow greater flow ability ${ }^{18}$. Chang et al. ${ }^{19}$ showed similar flow diameter for $\mathrm{AH}$ Plus and Sealapex, in accordance with our findings. However, the authors found that the complex viscosities of these sealers were significantly different. Therefore, they stated that the flow of root canal sealers evaluated using the conventional test provides limited information, leading to the search of new methodologies to complement this assessment.

Micro-CT is an innovative tool that provide high-resolution 3-dimensional evaluation of root canal fillings, allowing further exploration of precise internal structures of the sealers in a nondestructive way ${ }^{20}$. For this reason, micro-CT is considered as the gold standard for the filling analysis ${ }^{21}$. Based on this important characteristic to an accurate evaluation, Tanomaru-Filho et al. ${ }^{7}$ proposed a new technique for assessing flow and filling of root-end filling materials using micro-CT imaging. The authors stated that the test model proposed showed proper and reproducible results and could improve flow analysis. Moreover, this previous study observed an absence of correlation between the flow and filling properties. When using this technique to evaluate root canal sealers, and adding another diameter of test model, our results did not show difference between the sealers and the test models. These results probably occurred since no difference was observed in the flow property of the materials evaluated.

Araujo et al. ${ }^{21}$ used micro-CT to evaluate AH Plus, Sealapex and Endofill regarding their volume in the $1 \mathrm{~mm}$ apical third after obturation of the teeth. In this study, the lowest volume of sealer was observed in teeth filled with Sealapex and Endofill. The authors considered this fact as a better sealing ability for these materials and related this characteristic to the greater flow rate of these sealers. AH Plus was also related to a good filling ability ${ }^{* *}$, besides a low percentage of voids ${ }^{* * *}$.

\section{CONCLUSION}

Based on the methodologies used and the results obtained, we could conclude that AH Plus, Sealapex and Fill Canal have adequate flow and filling capacity, suggesting their clinical application. Micro-CT can be used to assess the flow and filling of root canal sealers by means of a single test.

\footnotetext{
***oizenblit RN, Soares FO, Lopes RT, Santos BC, Gusman H. Root canal filling quality of mandibular molars with EndoSequence BC and AH Plus sealers: a micro-CT study. Aust Endod J. 2019 Sep 26. In press. http://dx.doi.org/10.1111/aej.12373. PMid:31556201.

***Torres FFE, Zordan-Bronzel CL, Guerreiro-Tanomaru JM, Chavez-Andrade GM, Pinto JC, Tanomaru-Filho M. Effect of immersion in distilled water or phosphate-buffered saline on the solubility, volumetric change and presence of voids within new calcium silicate-based root canal sealers. Int Endod J. 2019 Sep 30. In press. http://dx.doi.org/10.1111/iej.13225. PMid:31566768.
} 


\section{ACKNOWLEDGEMENTS}

The authors thank Renato Luiz Carvalho for his assistance with the illustrations. The study was supported by the Coordenação de Aperfeiçoamento de Pessoal de Nível Superior - Brasil (CAPES) - Finance Code 001 and FAPESP (2016/00321-0 and 2017/19049-0).

\section{REFERENCES}

1. Celikten B, Jacobs R, Vasconcelos KF, Huang Y, Shaheen E, Nicolielo LFP, et al. Comparative evaluation of cone beam CT and micro-CT on blooming artifacts in human teeth filled with bioceramic sealers. Clin Oral Investig. 2019 Aug;23(8):3267-73. http://dx.doi.org/10.1007/s00784-018-2748-8. PMid:30488119.

2. Uzunoglu-Özyürek E, Kucukkaya Eren S, Karahan S. Effect of root canal sealers on the fracture resistance of endodontically treated teeth: a systematic review of in vitro studies. Clin Oral Investig. 2018 Sep;22(7):2475-85. http://dx.doi.org/10.1007/s00784-018-2540-9. PMid:29951975.

3. Schilder H. Filling root canals in three dimensions. J Endod. 2006 Apr;32(4):281-90. http://dx.doi.org/10.1016/j.joen.2006.02.007. PMid:16554195.

4. Torres FFE, Guerreiro-Tanomaru JM, Bosso-Martelo R, Espir CG, Camilleri J, Tanomaru-Filho M. Solubility, porosity, dimensional and volumetric change of endodontic sealers. Braz Dent J. 2019 Jul;30(4):368-73. http://dx.doi.org/10.1590/0103-6440201902607. PMid:31340227.

5. Carneiro SM, Sousa-Neto MD, Rached FA Jr, Miranda CE, Silva SR, Silva-Sousa YT. Push-out strength of root fillings with or without thermomechanical compaction. Int Endod J. 2012 Sep;45(9):821-8. http://dx.doi.org/10.1111/j.1365-2591.2012.02039.x. PMid:22458910.

6. International Organization for Standardization - ISO. ISO 6876: dental root canal sealing materials. Geneva: ISO; 2012.

7. Tanomaru-Filho M, Torres FFE, Bosso-Martelo R, Chavez-Andrade GM, Bonetti-Filho I, GuerreiroTanomaru JM. A novel model for evaluating the flow of endodontic materials using micro-computed tomography. J Endod. 2017 May;43(5):796-800. http://dx.doi.org/10.1016/j.joen.2016.12.002. PMid:28268019.

8. Bueno CR, Valentim D, Marques VA, Gomes-Filho JE, Cintra LT, Jacinto RC, et al. Biocompatibility and biomineralization assessment of bioceramic-, epoxy-, and calcium hydroxide-based sealers. Braz Oral Res. 2016 Jun;30(1):S1806-83242016000100267. http://dx.doi.org/10.1590/1807-3107BOR2016.vol30.0081. PMid:27305513.

9. Cintra LTA, Benetti F, de Azevedo Queiroz IO, Ferreira LL, Massunari L, Bueno CRE, et al. Evaluation of the cytotoxicity and biocompatibility of new resin epoxy-based endodontic sealer containing calcium hydroxide. J Endod. 2017 Dec;43(12):2088-92. http://dx.doi.org/10.1016/j.joen.2017.07.016. PMid:29032822.

10. Silva Almeida LH, Moraes RR, Morgental RD, Pappen FG. Are premixed calcium silicate-based endodontic sealers comparable to conventionaln materials? A systematic review of in vitro studies. J Endod. 2017 Apr;43(4):527-35. http://dx.doi.org/10.1016/j.joen.2016.11.019. PMid:28216270.

11. Cavalcanti AL, Limeira FI, Sales EA, Oliveira AA, Lima DM, Castro RD. In vitro antimicrobial activity of root canal sealers and calcium hydroxide paste. Contemp Clin Dent. 2010 Jul;1(3):164-7. http://dx.doi.org/10.4103/0976-237X.72784. PMid:22114408.

12. Tanomaru-Filho M, Cristine Prado M, Torres FFE, Viapiana R, Pivoto-João MMB, Guerreiro-Tanomaru JM. Physicochemical properties and bioactive potential of a new epoxy resin-based root canal sealer. 
Braz Dent J. 2019 Nov-Dec;30(6):563-8. http://dx.doi.org/10.1590/0103-6440201802861. PMid:31800750.

13. Marin-Bauza GA, Silva-Sousa YT, Cunha SA, Rached-Junior FJ, Bonetti-Filho I, Sousa-Neto MD, et al. Physicochemical properties of endodontic sealers of different bases. J Appl Oral Sci. 2012 JulAug;20(4):455-61. http://dx.doi.org/10.1590/S1678-77572012000400011. PMid:23032208.

14. Tanomaru-Filho M, Silveira GF, Tanomaru JM, Bier CA. Evaluation of the thermoplasticity of different gutta-percha cones and Resilon. Aust Endod J. 2007 Apr;33(1):23-6. http://dx.doi.org/10.1111/j.1747-4477.2007.00063.x. PMid:17461837.

15. Duarte MA, Ordinola-Zapata R, Bernardes RA, Bramante CM, Bernardineli N, Garcia RB, et al. Influence of calcium hydroxide association on the physical properties of AH Plus. J Endod. 2010 Jun;36(6):104851. http://dx.doi.org/10.1016/j.joen.2010.02.007. PMid:20478463.

16. Baras BH, Melo MAS, Sun J, Oates TW, Weir MD, Xie X, et al. Novel endodontic sealer with dual strategies of dimethylaminohexadecyl methacrylate and nanoparticles of silver to inhibit root canal biofilms. Dent Mater. 2019 Aug;35(8):1117-29. http://dx.doi.org/10.1016/j.dental.2019.05.014. PMid:31128937.

17. Baras BH, Wang S, Melo MAS, Tay F, Fouad AF, Arola DD, et al. Novel bioactive root canal sealer with antibiofilm and remineralization properties. J Dent. 2019 Apr;83:67-76. http://dx.doi.org/10.1016/j.jdent.2019.02.006. PMid:30825569.

18. Bernardes RA, Campelo AA, Silva DS Jr , Pereira LO, Duarte MA, Moraes IG, et al. Evaluation of the flow rate of 3 endodontic sealers: Sealer 26, AH Plus, and MTA Obtura. Oral Surg Oral Med Oral Pathol Oral Radiol Endod. 2010 Jan;109(1):e47-9. http://dx.doi.org/10.1016/j.tripleo.2009.08.038.

PMid:20123369.

19. Chang SW, Lee YK, Zhu Q, Shon WJ, Lee WC, Kum KY, et al. Comparison of the rheological properties of four root canal sealers. Int J Oral Sci. 2015 Mar;7(1):56-61. http://dx.doi.org/10.1038/ijos.2014.33. PMid:25059248.

20. Huang Y, Celikten B, Vasconcelos KF, Nicolielo LFP, Lippiatt N, Buyuksungur A, et al. Micro-CT and nano-CT analysis of filling quality of three different endodontic sealers. Dentomaxillofac Radiol. 2017 Dec;46(8):20170223. http://dx.doi.org/10.1259/dmfr.20170223. PMid:28845679.

21. Araujo VL, Souza-Gabriel AE, Cruz AM Fo, Pecora JD, Silva RG. Volume of sealer in the apical region of teeth filled by different techniques: a micro-CT analysis. Braz Oral Res. 2016;30(1):e27. http://dx.doi.org/10.1590/1807-3107BOR-2016.vol30.0027. PMid:27050936.

\section{CONFLICTS OF INTERESTS}

The authors declare no conflicts of interest.

\section{*CORRESPONDING AUTHOR}

Mário Tanomaru-Filho, UNESP - Universidade Estadual Paulista, Faculdade de Odontologia de Araraquara, Departamento de Odontologia Restauradora, Rua Humaitá, 1680, 14801-903 Araraquara - SP, Brasil, e-mail: tanomaru@uol.com.br 